\title{
The Differences of Improving Communication Ability and Mathematical Concepts Understanding between Students that Given Problem Based Learning and Discovery Learning at SMP Swasta Al-Hikmah Medan
}

\author{
Oktavia Dwi Rennita \\ Mathematics Education Program, Post Graduate Program \\ Universitas Negeri Medan, Indonesia \\ Asmin \\ Mathematics Education Program, Post Graduate Program \\ Universitas Negeri Medan, Indonesia \\ Faiz Ahyaningsih \\ Mathematics Education Program, Post Graduate Program \\ Universitas Negeri Medan, Indonesia \\ Ellyana Sari Harahap \\ Mathematics Education Program, Post Graduate Program \\ Universitas Negeri Medan, Indonesia
}

\begin{abstract}
This study aims to analyze (1) The Differences of Improving Communication Ability and Mathematical Concepts Understanding between Students that Given Problem Based Learning and Discovery Learning, (2) There is an interaction between the learning model with the students' initial ability of mathematics (KAM) towards improving students' communication ability and mathematical concepts understanding. The type of this research was quasi-experimental. This study was conducted at SMP Swasta AlHikmah. The population in this study was all students of class VIII by taking a sample of two classes. The instrument used consists of students' mathematical communication test and understanding concepts. The instruments fulfilled the requirements of content validity and high reliability, i.e. 0.789 and 0.793 respectively for mathematical communication and concepts understanding ability. Data were analyzed by the Two Way Anova test. Before using the Two Way Anova test, homogeneity and normality were tested first in this study with a significant level of $5 \%$. Based on the results of the analysis, the results of the study were: (1) there was the difference of improving communication ability and mathematical concepts understanding between students that given problem-based learning and discovery learning, (2) there is interaction between the learning model with the students' initial ability of mathematics towards improving students' communication ability and mathematical concepts understanding.
\end{abstract}

Keywords: mathematical communication ability, understanding of mathematical concepts, problem based learning model, discovery learning model and students' initial ability of mathematics

\section{BACKGROUND}

Mathematics as a basic science and is one of the subjects of the National Examination (UN). Mathematics with its various roles makes it a very important science, and one of the roles of mathematics as a thinking tool to deliver students understand the mathematical concepts they 
Rennita, O. D., Asmin., Ahyaningsih, F., \& Harahap, E. S. (2018). The Differences of Improving Communication Ability and Mathematical Concepts Understanding between Students that Given Problem Based Learning and Discovery Learning at SMP Swasta Al-Hikmah Medan. Advances in Social Sciences Research Journal, 5(10) 597-608.

are learning. Based on its development, the problems faced in learning mathematics are increasingly complicated and require a more perfect analysis structure. So that in learning is indispensable good way of communicating, so as to be able to solve mathematical problems.

National Council of Teachers of Mathematics (1989) formulated the learning objectives of mathematics, namely: (1) learning to communicate (mathematical communication); (2) learning to reason (mathematical reasoning); (3) learning to solve problems (mathematical problem solving); (4) learning to associate ideas (mathematical connections); and (5) the formation of positive attitudes towards mathematics. This goal shows how important learn of mathematics is, because by learning mathematics certain abilities and skills are useful not only when learning mathematics but also can be applied in solving various problems in daily life. Mathematical communication ability is one of the important abilities in learn of mathematics, including if the communication process is well established, it can help students build their understanding of mathematical ideas and make them easier to understand (Mahmudi, 2009: 7).

Whereas in the opinion of Baroody (1993), learning must be able to help students communicate mathematical ideas through five aspects of communication, namely representating, listening, reading, discussing and writing. Next, there are at least two important reasons why communication in learning mathematics needs to be developed among students. First, mathematics as language, meaning that mathematics is not just a tool of thinking (a tool to aid thinking), a tool for finding patterns, solving problems or drawing conclusions, but also mathematics "an invaluable tool for communicating a variety of ideas clearly, precisely, and succinctly". Second, mathematics learning as social activity : it means as a social activity in learning of mathematics as a vehicle for interaction between students, as well as a means of communication between teachers and students. Mathematical communication needs to be the focus of attention in learning of mathematics, because through communication, students can organize and consolidate their mathematical thinking and students can explore mathematical ideas. Awareness of the importance of paying attention to students' ability to communicate with using mathematics learned at school needs to be grown, because one of the functions of mathematics is as a way of communicating ideas in a practical, systematic and efficient manner.

Kilpatrick, J., Swafford, J., \& Findell, B (2001: 116) mention that "concepual understandingcomprehension of mathematical concepts, operations, and relations". They argue that concept understanding is one of the mathematical skills that students must master in mathematics learning. Because students will not be able to solve problems in mathematics if the student does not understand correctly the concept of mathematical problems given.

Students' knowledge and understanding of mathematical concepts can be seen from several aspects or indicators, NCTM (1989: 48) formulates aspects of understanding mathematical concepts as follows: The assesment of sudents' knowledge and understanding of mathematical concepts should provide evidence that they can: 1) label, verbalize, and define concepts; 2) identify and generate examples and non example; 3) use models, diagrams, and symbols to represent concepts; 4) identify properties of a given concept and recognize conditions that determine a particular concept; 5) compare and contrast concepts. The low student learning outcomes can be seen from the results of the answers of some students who were given a description problem. The provision of this question aims to see the ability to understand students' concepts and mathematical communication in solving problems that demand 
thinking and reasoning skills. Sampling results from students' answers were carried out by purposive sampling.

From the solution of the problem that has been done by several students, the average score obtained by students is 50 . In general, it can be concluded that the ability to understand students mathematical concepts is low. It can be seen that the ability of students to restate a concept by using their own language is still low, and the ability of students to use concepts in problem solving is still low. This is because students do not understand the problem given. So that students are not able to solve problems properly and correctly.

Based on the reality of the above problems, it is necessary to look for models and learning approaches that are able to improve mathematical problem solving skills. One model of learning that is creative, innovative, and effective in improving communication skills and understanding of students' mathematical concepts that researchers will do is a problem-based learning model. According to Arends (2008) this model is learning in which students work on authentic (real) problems with the intention of compiling their own knowledge, developing inquiry and higher-order thinking skills, developing independence and increasing their confidence.

Not only problem-based learning models that will improve communication skills and understanding of mathematical concepts but researchers will also apply the discovery learning model. According Takdir (2012) discovery learning is one model that allows students to be directly involved in teaching and learning activities so that they are able to use their mental processes to find a concept or theory being studied.

Students' mathematics learning achievement is not only from learning that uses problembased learning models or discovery learning alone, but also influenced by their initial mathematical abilities as well. Bryant dan Nunez (dalam Aunino, P. \& Niemivirta, M, 2010:1) suggested that "logical thinking, teaching of conventional counting systems, and a meaningful context for learning mathematics form the basis for children's early mathematical development". Initial ability of mathematics is the initial knowledge ability that must be possessed by a student which is a prerequisite for learning further lessons and to be able to easily continue their education to the next level.

Based on the background of the above problems, it is necessary to find out whether the problem-based learning and discovery learning models have difference in contributions to the communication ability and mathematical concepts understanding students.

\section{THEORETICAL FRAMEWORK}

Mathematical communication, a fundamental mathematics educational objective that involves cognitive and social activities (Baroody \& Ginsburg, 1990), is used to engage students in communicative situations for increasing learning interaction with others to obtain mutual mathematical ideas (Silver \& Smith, 1996), share mathematical thoughts, develop mathematical concepts and strategies, and reflect on their current mathematical understanding (Whitin \& Whitin, 2000; Cooke \& Buchholz, 2005). Mathematical communication abilities also include expressing mathematical thought by using mathematical language clearly, precisely, and succinctly (National Council of Teachers of Mathematics, 2000); understanding others' mathematical equations and concepts (Lin \& Lee, 2004; Lin, Shann, \& Lin, 2008); and evaluating others' mathematical concepts by, for example, asking meaningful questions and explaining the reasons for others' incorrect mathematical thought (Lin \& Lee, 2004). 
Various means of fostering mathematical communication abilities have been proposed. For example, Baroody and Ginsburg (1990) suggested that students should communicate mathematical ideas through representing, listening, discussing, reading, and writing. Cobb, Boufi, McClain, and Whitenack (1997) also claimed that students' mathematical discourse in classrooms can support their conceptual development, while Shimizu and Lambdin (1997) revealed that students who write about the thinking process of their solutions can organize complex thoughts and evaluate their own opinions. Similarly, Steele and Arth (1998) argued that reflecting on how to solve a problem by writing their solutions can facilitate students to explain their thinking process more clearly, thereby benefitting themselves in learning mathematics and learning to communicate mathematically by constructing mathematical artifacts as well as developing and evaluating mathematical arguments (National Council of Teachers of Mathematics, 2000). Similarly, students can adopt written mathematical communication by using text, figures, Tabels, pictures, diagrams, or mathematical symbols to provide critical evidence of their mathematics ideas and concepts (Mooney, Hansen, Ferrie, Fox, \& Wrathmell, 2012; Whitin \& Whitin, 2000).

Conceptual knowledge is a grasp of the mathematical concepts and ideas that are not problemspecific and therefore can be applied to any problem solving situation conceptual knowledge is a grasp of the mathematical concepts and ideas that are not problem-specific and therefore can be applied to any problem solving situation (Madhavi, 2008). Conceptual knowledge as explicit or implicit understanding of the principles that govern a domain and of the interreletion pieces between knowledge in domain. conceptual knowledge as explicit or implicit understanding of the principles that govern a domain and of the interreletion pieces between knowledge in domain (Rittle, 2001). Conceptual understanding is the over-arching understanding of mathematical concepts and ideas that one often refers to as a good mathematical sense (Madhavi, 2008). According to Duffin \& Simpson (2000) understanding of concepts as students' ability to: (1) explain concepts, can mean students are able to re-express what has been communicated to them; (2) using concepts in a variety of different situations; and (3) developing some of the consequences of a concept, meaning that students understand a concept as a result of students having the ability to solve every problem correctly.

\section{RESEARCH METHODS}

This research is categorized into quasi-experimental research. This study aims to analyze differences in the improvement of communication ability and mathematical concepts understanding between students who were given a problem-based learning model with students who were given a discovery learning model, as well as to analyze the interaction between learning models with Initial ability of mathematics students to improve communication ability and mathematical concepts understanding students.

The population in this study were all eighth grade students of Al-Hikmah Medan Private Junior High School 2018/2019 which amounted to 160 people. The sampling in this study uses the Slovin formula with purposive sampling technique. The sample of this study consisted of two classes, namely class VIII-1 as the experimental class 1 with a total of 32 students and VIII-2 as the experimental class 2 with a total of 32 students. The design used in this study is pretest posttest control group design. The research design is presented in Tabel 1: 
Tabel 1. Research Design

\begin{tabular}{|c|c|c|c|}
\hline Treatment Group & Pretest & Treatment & Postest \\
\hline $\begin{array}{c}\text { PBM } \\
\text { (Eksperimental 1) }\end{array}$ & $\mathrm{O}_{1}$ & $\mathrm{X}_{1}$ & $\mathrm{O}_{2}$ \\
\hline $\begin{array}{c}\text { Discovery Learning } \\
\text { (Eksperimental 2) }\end{array}$ & $\mathrm{O}_{1}$ & $\mathrm{X}_{2}$ & $\mathrm{O}_{2}$ \\
\hline
\end{tabular}

\section{Information:}

$\mathrm{O}_{1}$ : Observation 1 (pretest: test communication ability and mathematical concepts understanding)

$\mathrm{O}_{2}$ : Observation 2 (posttest: test communication ability and mathematical concepts

understanding)

$\mathrm{X}_{1}$ : Treatment of learning with problem-based learning models

$\mathrm{X}_{2}$ : Treatment of learning with discovery learning models

This study uses one type of instrument, namely the test instrument. The test used is a test of mathematical communication skills and a test of the ability to students Mathematical Concepts Understanding.

\section{DATA ANALYSIS \& RESULT}

To answer the research questions raised in the introduction, an analysis and interpretation of research result data is needed. The analysis in question is to find out the difference in the improving of communication ability and mathematical concepts understanding of students in the material of the linear equation system of two variables that obtain learning with different models. The experimental class 1 obtained learning with a problem-based learning model, while the experimental class 2 obtained learning with discovery learning. Furthermore, it will be seen also the interaction between learning (problem-based learning and discovery learning models) with students 'initial mathematical abilities (high, medium and low) towards improving communication ability and mathematical concepts understanding students.

The mathematical communication ability test is done twice, namely the initial test (pretest) and the final test (posttest) with the equivalent type of question. The initial and final tests were followed by 32 students for each class so that in the data analysis that became the subject of this study were 32 people who took the initial test (pretest) and the final test (posttest). Based on the pretest data obtained the lowest score $\left(\left(\mathrm{X}_{\min }\right)\right)$, highest score $\left(x_{\text {maks }}\right)\left(\mathrm{X}_{\text {max }}\right)$, average score $((\overline{\mathrm{X}}))$ and standard deviation $(S D)$ for experimental class 1 and experimental class 2 as in Tabel 2 below:

Tabel 2. Result Data Pretest and Posttest of Mathematical Communication Ability

\begin{tabular}{|c|c|c|c|c|c|c|}
\hline \multicolumn{7}{|c|}{ Result of Pretest } \\
\hline Class & Ideal Score & $\mathbf{N}$ & $X_{\min }$ & $X_{\text {maks }}$ & $\bar{x}$ & SD \\
\hline Eksperimen I & \multirow{2}{*}{100} & 32 & 6,25 & 75,00 & 43,56 & 19,08 \\
\hline Eksperimen II & & 32 & 6,25 & 56,25 & 30,27 & 14,21 \\
\hline \multicolumn{7}{|c|}{ Result of Posttest } \\
\hline Class & Ideal Score & $\mathbf{N}$ & $X_{\min }$ & $X_{\text {maks }}$ & $\bar{x}$ & SD \\
\hline Eksperimen I & \multirow{2}{*}{100} & 32 & 50 & 100 & 78,13 & 14,72 \\
\hline Eksperimen II & & 32 & 43,75 & 93,75 & 71,68 & 12,50 \\
\hline
\end{tabular}


To see the improving of mathematical communication ability between students who obtain learning with a problem-based learning model with students obtaining a discovery learning model is to calculate the gain of both classes. Normalized gain test results can be seen in Tabel 3 below:

Tabel 3. Result Data Improving of Mathematical Communication Ability

\begin{tabular}{|c|c|c|c|c|c|}
\hline \multirow{2}{*}{ Class } & \multicolumn{5}{|c|}{ Score of Data $\boldsymbol{N}$-Gain } \\
\cline { 2 - 6 } & $x_{\min }$ & $x_{\text {maks }}$ & $\bar{x}$ & SD & Predicate \\
\hline Eksperimen 1 & 0,20 & 1,00 & 0,627 & 0,230 & Medium \\
\hline Eksperimen 2 & 0,36 & 0,88 & 0,602 & 0,141 & Medium \\
\hline
\end{tabular}

Furthermore, the concept comprehension test was conducted twice, namely the initial test (pretest) and the final test (posttest) with the equivalent type of question. Based on the pretest data obtained the lowest score $\left(x_{\min }\right)$, highest score $\left(x_{\text {maks }}\right)$, average score $(\bar{x})$ and standard deviation $(S D)$ for experimental class 1 and experimental class 2 as in Tabel 4 below:

Tabel 4. Result Data Pretest and Posttest of Understanding of Mathematical Concepts Ability Result of Pretest

\begin{tabular}{|c|c|c|c|c|c|c|}
\hline Class & Ideal Score & $\mathbf{N}$ & $X_{\min }$ & $X_{\text {maks }}$ & $x$ & SD \\
\hline Eksperimen I & \multirow{2}{*}{100} & 32 & 6,25 & 75,00 & 43,56 & 19,08 \\
\hline Eksperimen II & & 32 & 6,25 & 56,25 & 30,27 & 14,21 \\
\hline \multicolumn{7}{|c|}{ Result of Posttest } \\
\hline Class & Ideal Score & $\mathbf{N}$ & $\boldsymbol{X}_{\min }$ & $X_{\text {maks }}$ & $\bar{x}$ & SD \\
\hline Eksperimen I & \multirow{2}{*}{100} & 32 & 50 & 100 & 78,13 & 14,72 \\
\hline Eksperimen II & & 32 & 43,75 & 93,75 & 71,68 & 12,50 \\
\hline
\end{tabular}

To see an improving in mathematical concepts understanding ability of students between students who obtain learning with a problem-based learning model with students obtaining a discovery learning model is to calculate the gain of both classes. Normalized gain test results can be seen in Tabel 5 below:

Tabel 5. Result Data Improving of mathematical concepts understanding ability

\begin{tabular}{|c|c|c|c|c|c|}
\hline \multirow{2}{*}{ Class } & \multicolumn{5}{|c|}{ Score of Data $\boldsymbol{N}$-Gain } \\
\cline { 2 - 6 } & $x_{\min }$ & $x_{\text {maks }}$ & $\bar{x}$ & SD & Predicate \\
\hline Eksperimen 1 & 0,38 & 1,00 & 0,649 & 0,150 & Medium \\
\hline Eksperimen 2 & 0,36 & 0,85 & 0,589 & 0,117 & Medium \\
\hline
\end{tabular}

Furthermore, it is necessary to examine the significance of differences of improving of mathematical communication ability in problem-based learning models and discovery learning models which were analyzed by two-way variant analysis statistical tests. Two-way ANOVA is used after fulfilling the analytical prerequisite test which is normality test and homogeneity test. The two-way Anova test results are presented in Tabel 6 below: 
Tabel 6. Test Results of ANOVA on Improving of Students' Mathematical Communication

Ability Based on Learning

Tests of Between-Subjects Effects

Dependent Variable: Mathematical Communication Ability

\begin{tabular}{|l|c|c|c|c|c|}
\hline Source & $\begin{array}{c}\text { Type III Sum } \\
\text { of Squares }\end{array}$ & df & $\begin{array}{c}\text { Mean } \\
\text { Square }\end{array}$ & F & Sig. \\
\hline Corrected Model & $82,757^{a}$ & 5 & 16,551 & 6,189 &, 000 \\
\hline Intercept & 3946,379 & 1 & 3946,379 & 1475,739 &, 000 \\
\hline $\begin{array}{l}\text { Initial of Mathematical } \\
\text { Ability (KAM) }\end{array}$ & 49,514 & 2 & 24,757 & 9,258 &, 000 \\
\hline Lesrning & 28,858 & 1 & 28,858 & 10,791 &, 002 \\
\hline Learmimg * KAM & 14,743 & 2 & 1,371 & 5,513 &, 018 \\
\hline Error & 155,102 & 58 & 2,674 & & \\
\hline Total & 7231,000 & 64 & & & \\
\hline Corrected Total & 237,859 & 63 & & & \\
\hline a. R Squared = 348 (Adjusted R Squared $=, 292)$ & & & \\
\hline
\end{tabular}

Furthermore, the results of descriptive analysis of the data on the ability to understanding of mathematical concepts students in the two learning groups are presented in Tabel 7 below:

Tabel 7. Test Results of ANOVA on Improving of mathematical concepts understanding ability Based on Learning

\begin{tabular}{|l|c|c|c|c|c|}
\hline \multicolumn{7}{|c|}{ Tests of Between-Subjects Effects } \\
\hline Dependent Variable: & Understanding of Mathematical Concept & Sig. \\
\hline Source & $\begin{array}{c}\text { Type III Sum } \\
\text { of Squares }\end{array}$ & $\mathrm{df}$ & $\begin{array}{c}\text { Mean } \\
\text { Square }\end{array}$ & $\mathrm{F}$ &, 000 \\
\hline Corrected Model & $95,692^{\mathrm{a}}$ & 5 & 19,138 & 8,763 &, 000 \\
\hline Intercept & 5459,381 & 1 & 5459,381 & 2499,812 &, 000 \\
\hline $\begin{array}{l}\text { Initial of Mathematical } \\
\text { Ability (KAM) }\end{array}$ & 42,428 & 2 & 21,214 & 9,714 &, 007 \\
\hline Lesrning & 11,408 & 1 & 11,408 & 5,224 &, 038 \\
\hline Learmimg * KAM & 5,169 & 2 & 2,585 & 4,501 & \\
\hline Error & 126,667 & 58 & 2,184 & & \\
\hline Total & 9753,000 & 64 & & & \\
\hline Corrected Total & 222,359 & 63 & & & \\
\hline a. R Squared = $=430$ (Adjusted R Squared $=, 381)$ &
\end{tabular}

\section{Mathematical Communication Ability}

\section{DISCUSSION}

Based on the results of the study it was found that the average pretest of mathematical communication ability in the experimental class I, namely the class that uses mathematics learning with problem-based learning model of 43.56 while in experimental class II, namely classes that use discovery learning models of 30.27 . In addition, the average posttest of mathematical communication ability in the experimental class I was 78.13; while in experimental class II it was 71.68. This shows that there are differences in the improving of mathematical communication ability in the experimental class I and experimental class II.

To measure the difference in the improving of mathematical communication ability, the calculation of the gain index in experimental class I and experimental class II was obtained and the average gain index of the mathematical communication ability test results in experimental class I was 0.627 while in experimental class II it was 0.602 so that there was a difference in ability significant mathematical communication in experimental class I and experimental class II. In learning activities, students who have mathematical communication ability can help other students who have problems understanding the subject matter. The results obtained in this 
study indicate that mathematics learning with problem-based learning models can improve the mathematical communication ability possessed by students.

The results of the study are in line with the results of Furaiza, Syahputra and rajagukguk (2018) have conducted research with the title of research on "Differences in metacognition and mathematical communication ability between students taught using problem based learning model and numbered head together cooperative learning model at SMP Kartika 1-2 Medan". The findings and results of this study have provided information there is difference of mathematical communication ability students' taught using PBL model with NHT cooperative Learning model.

Furthermore, Surya, Syahputra and Juniati (2018) in her research entitled "Effect of problem based learning toward mathematical communication ability and self regulated learning". The results showed that a significant difference model (PBL, Conventional) on the ability of mathematical communication, the average difference communication abilities of female students is higher than male students is 16.202 compared to male students 14.769 .

Furthermore, Eviyanti, Surya, Syahputra (2017: 138) in her research entitled "Improving the students' mathematical problem solving ability by applying problem based learning model in VII grade at SMPN 1 Banda Aceh Indonesia". The results of quantitative data testing indicate that the data is normally distributed, which can be analyzed with the statistics of one sample ttest at a significance value of $\alpha=0.05$, based on $\mathrm{N}$-Gain data analysis scores of mathematical problem solving abilities obtain thitung $=3.7$ and $t$ Tabel $=1,67$ or $t_{\text {count }}>\mathrm{t}_{\text {Tabel }}$ is $3.7>1.67$, that means $\mathrm{H}_{0}$ is rejected and consequently $\mathrm{H}_{1}$ is accepted. From the results of this study concluded that the improvement of students' mathematical problem-solving abilities that get application of problem-based learning models is better than students who get conventional learning material opportunities.

\section{Mathematical Concept Understanding Ability}

Based on the results of the study, it was found that the average pretest in mathematical concepts understanding ability in the experimental class I, namely the class that uses mathematics learning with problem-based learning model of 49.02 while in experimental class II, the class uses discovery learning model of 30,27. In addition, result of the average posttest in ability on mathematical concepts understanding ability in the experimental class I was 81.64; while in experimental class II it was 70.90. This shows that there are differences of improving in mathematical concepts understanding ability in the experimental class I and experimental class II. To measure the difference of improving in mathematical concepts understanding ability, the calculation of the gain index in the experimental class I and experimental class II was obtained and the average gain index of the mathematical concept comprehension test results in the experimental class I was 0.649 while in experimental class II it was 0.589 so there was a difference improving ability to understand significant mathematical concepts in experiment class I and experimental class II.

In learning activities, students who have the $\mathrm{v}$ can help other students who have problems understanding the subject matter. The results obtained in this study indicate that mathematics learning with problem-based learning models can improve the mathematical concepts understanding ability possessed by students. The results of the study are in line with the results of the research by Hidayat and Iksan (2015: 2438) in their research "the effect of realistic mathematics education on students' conceptual understanding of linear programming". The results showed that there were significant differences between treatment 
groups and control of conceptual understanding. There is a significant relationship between conceptual understanding and mathematics learning outcomes in linear program material. Concept errors in linear program material in the treatment group were lower than in the control group. The implications of this research are useful for educators to help mathematical concepts understanding ability students through open and contextual questions so that students can think mathematically, not work mathematically.

\section{Interaction between Learning Model with Initial Ability of Mathematics (KAM) towards Differences of Improving Mathematical Communication Ability}

Based on the results of the study, it was found that the average gain index of the results of mathematical communication tests on students with high, medium, and low ability in the experimental class I, is the class given mathematics learning with each problem-based learning model of height (0.83), medium (0.61), and low (0.35). Whereas, the average gain index of students' mathematical communication ability test results were given a discovery learning model in each group of high ability students (0.80), medium (0.59), and low (0.57).

Based on the average difference, it appears that students with high categories gain greater benefits from problem-based learning with the difference in initial ability of mathematics scores of high (0.03), medium (0.02) and low (-0.22). In this case, initial ability of mathematics influences the improving of students' mathematical communication ability, because students with high and medium initial ability of mathematics categories have a greater improving than low category initial ability of mathematics. The results of the two-way ANOVA calculation on the score of the experimental group I posttest (problem-based learning model) and experimental group II (discovery learning model) obtained $\mathrm{F}_{\text {count }}$ in factor initial ability of mathematics is 9,258 with a significance level of 0,000 . Because $0,000<=0,05$ then it can be concluded that grouping of initial ability of mathematics also influences students' mathematical communication ability.

From the results of the analysis carried out on the learning model with initial ability of mathematics on improving mathematical communication ability students indicate that there is interaction. For learning factors related to initial ability of mathematics, $\mathrm{F}_{\text {count }}$ is 5.513 with a significant level of $0.018 ;(0.018<=0,05)$ then $\mathrm{H} 0$ is rejected which means that there is an interaction between learning factors with the initial ability of mathematics of students towards the improving of students' mathematical communication ability. This shows that problembased learning and dsicovery learning models have an influence on students 'mathematical communication ability, whereas if associated with initial ability of mathematics also influences students' mathematical communication ability. Then it can be concluded that in this study there is an interaction between learning (problem-based learning and disccovery learning) with the students 'initial ability level (high, medium and low) towards improving students' mathematical communication ability.

The results of the study are also in line with the results of research from Furaiza, Syahputra and Rajagukguk (2018) in their research entitled "Diffrences in metacognition and mathematical communication ability between students taught using problem based learning model and numbered head together cooperative learning model at SMP Kartika 1-2 Medan". The results of his research conclude that There is an interaction between learning model with student's early math ability to mathematical communication ability. This means that the interaction between learning model and early math ability (high, medium, low) contributes equally to the students' mathematical communication abilities. 
Interaction between Learning Model with Initial Ability of Mathematics towards Differences of Improving Mathematical Concept Understanding Ability

Based on the results of the study it was found that the average gain index of the results of the mathematical concepts understanding ability in students of high, medium, and low ability in the experimental class I, namely the class given mathematics learning with each problembased learning model of height (0.71) , medium (0.63), and low (0.58). Whereas, the average gain index of the mathematical concepts understanding ability student is given a discovery learning model in each group of high ability students (0.78), medium (0.57), and low (0.57).

Based on the average difference, it appears that students with high categories gain greater benefits from problem-based learning with the difference in intial ability of mathematics scores high (0.07), moderate (0.06) and low (0.00). In this case, initial ability of mathematics influences the mathematical concepts understanding ability, because students with categories high and medium intial ability of mathematics have a greater improve than low category initial ability of mathematics.

The results of the two-way ANAVA calculation on the posttest score of the experimental group I (problem-based learning model) and experimental group II (discovery learning model) obtained a $F_{\text {count }}$ of factor initial ability of mathematics is 9,714 with a significant level of 0.000 . Because $0,000<=0,05$ then it can be concluded that initial ability of mathematics grouping also affects the mathematical concepts understanding ability student.

From the results of the analysis carried out on learning models with intial ability of mathematics to improving of mathematical concepts understanding ability students indicate that there is interaction. For learning factors related to initial ability of mathematics, $\mathrm{F}_{\text {count }}$ is 4.501 with a significant level of $0.038 ;(0.038<=0,05)$ then $\mathrm{H}_{0}$ is rejected which means that there is an interaction between learning factors with the initial ability of mathematics (KAM) of students towards improving the mathematical concepts understanding ability students. This shows that the problem-based learning and dsicovery learning models have an influence on the ability mathematical concepts understanding ability, whereas if associated with initial ability of mathematics also influences the mathematical concepts understanding ability students.

Then it can be concluded that in this study there is an interaction between learning (problembased learning and disccovery learning) with the initial ability level of students (high, medium and low) to imrpoving of mathematical concepts understanding ability.

\section{CONCLUSION}

Based on some theories, research findings, and research discussions, it can be concluded that :

1. There was the difference of improving mathematical communication ability and concepts understanding between students that given problem-based learning and discovery learning,

2. There is interaction between the learning model with the students' initial ability of mathematics towards improving students' mathematical communication and concepts understanding ability. 


\section{References}

Arends, R. 2008. Learning to Teach. Yogyakarta: Pustaka Pelajar

Aunino, P \& Niemivirta, M. 2010. Predicting Children's Mathematical Performances In Grade One By Early Numeracy. USA: Department of Psychological and Brain Sciences, Johns Hopkins University, (Online). Learning and Individual Differences. Journal Homepage: (www.elsevier.com/locate/lindif, 15 september 2017).

Baroody, A.J. 1993. Problem Solving, Reasoning and Communicating, K-8. Helping Children think Mathematically. New York: Merril, an inprint of Macmillan Publishing, Company

Baroody, A. J., \& Ginsburg, H. P. (1990). Children's mathematical learning: A Cognitive view. In C. Maher \& N. Noddings (Eds.), Constructivist views on the teaching and learning of mathematics (pp. 51-64). Reston, VA: National Council of Teachers of Mathematics

Cobb, P., Boufi, A., McClain, K., \& Whitenack, J. (1997). Reflective discourse and collective reflection. Journal for Research in Mathematics Education, 28(3), 258-277.

Cooke, B. D., \& Buchholz, D. (2005). Mathematical communication in the classroom: A Teacher makes a difference. Early Childhood Education Journal, 32(6), 365-369

Duffin, J.M \& Simpson, A.P. 2000. A Searchfor Understanding. Journal of Mathematical Behavior. 18 (4): $415-427$

Eviyanti, C.Y., Surya, E., Syahputra, E \& Simbolon, M. 2017. Improving the Students' Mathematical Problem Solving Ability by Applying Problem Based Learning Model in VII Grade at SMPN 1 Banda Aceh Indonesia. International Journal of Novel Research in Education and Learning. Vol.4, Issue 2, pp:138-144). ISSN 2394-9686

Furaiza, A., Syahputra, E \& Rajagukguk, W. 2018. Differences in Metacognition and Mathematical Communication Ability Between Students Taught Using Problem Based Learning Model and Numbered Head Together Cooperative Learning Model at SMP Kartika 1-2 Medan. Journal of Education and Practice. Vol.9 No.7. ISSN 222-288X

Hidayat, R \& Iksan, Z.H. 2015. The Effect of realistic Mathematics education on students' Conceptual Understanding of Linear Programming. Scientific Research Publishing. Vol. 6. ISSN 2438-2445

J. Kilpatrick., Swafford, J \& Findell, B. 2001. Adding It Up: Helping Children Learn Mathematics. Washington DC: National Academy Press

Lin, C. S., Shann, W. C., \& Lin, S. C. (2008). Reflections on mathematical communication from Taiwan math curriculum guideline and PISA 2003. Retrieved from http://www.criced.tsukuba.ac.jp/math/apec/apec2008/papers/PDF/16.Lin_Su_Chun_Taiwan.pdf

Lin, Y. H., \& Lee, Q. Y. (2004). 國小學生數學解題溝通能力評量之實證研究 [A Study of ability on mathematical communication for pupils of elementary schools]. Journal of Educational Measurement and Statistics, 12, $233-268$.

Madhavi. J., Russel, G \& Scott, B. 2008. Conceptual Understanding Is The Over-Arching Understanding Of Mathematical Concepts And Ideas that One Often Refers To As A Good Mathematical sense. [Online]. Tersedia: (http://files.eric.ed.gov/fulltext/ED521882.pdf)

Mahmudi, A. 2009. Komunikasi dalam pembelajaran Matematika. Makalah Termuat pada Jurnal MIPMIPA UNHALU. Vol.8 No.1

Mooney, C., Hansen, A., Ferrie, L., Fox, S., \& Wrathmell, R. (2012). Primary mathematics: Knowledge and understanding. Exeter,UK: Learning Matters

NCTM. 1989. Curriculum and Evaluation Standards for School Mathematics. Reston, Virginia: The National Council of Teachers of mathematics.

National Council of Teachers of Mathematics. (2000). Principles and standards for school mathematics. Reston, VA: National Council of Teachers of Mathematics

Shimizu, Y., \& Lambdin, D. V. (1997). Assessing students' performance on an extended problem-solving task: A Story from a Japanese classroom. The Mathematics Teacher, 90(8), 658-664.

Silver, E. A., \& Smith, M. S. (1996). Building discourse communities in mathematics classrooms: A Worthwhile but challengingjourney. In P. C. Elliott (Ed.), Communication in mathematics, K-12 and beyond: 1996 yearbook (pp. 2028). Reston, VA: National Council of Teachers of Mathematics.

Surya, E., Syahputra, E \& Juniati, N. 2018. Effect of Problem Based Learning Toward Mathematical Communication Ability and Self-Regulated Learning. Journal of Education and Practice. Vol. 9 No.6. ISSN 222-288X

Steele, D. F., \& Arth, A. A. (1998). Math instruction and assessment: Preventing anxiety, promoting confidence. Schools in the Middle, 7(3), 44-48. 
Rennita, O. D., Asmin., Ahyaningsih, F., \& Harahap, E. S. (2018). The Differences of Improving Communication Ability and Mathematical Concepts Understanding between Students that Given Problem Based Learning and Discovery Learning at SMP Swasta Al-Hikmah Medan. Advances in Social Sciences Research Journal, 5(10) 597-608.

T. Eckes, The Developmental Social Psychology of Gender, Lawrence Erlbaum, 2000. [E-book] Available: netLibrary e-book

Takdir, I. 2012. Pembelajaran Discovery Strategy dan Mental Vocational Skill. Yogyakarta: Diva Press

Whitin, P., \& Whitin, D. J. (2000). Math is language too: Talking and writing in the mathematics classroom. Reston, VA: National Council of Teachers of Mathematics 